\title{
THE RELATIVE EFFECTIVENESS OF AL-QUR'AN MUROTAL AND CLASSICAL MUSIC THERAPY ON IMPROVING CONCENTRATION ABILITY INAUTISTIC CHILDREN AT SLB SEMESTA, SOOKO, MOJOKERTO
}

\author{
Yufi Aris Lestari, Aris Hartono, Yulianto, Hartin Suidah, Herlina, \\ Heppy Rina Mardiana, Amalia Dwi Adelia Cristi
}

School of Health Sciences Dian Husada, Mojokerto, East Java

\begin{abstract}
Background: Autistic children have cognitive limitation. Autism affects the concentration disorder, which has a great impact on the learning process. Music therapy may increase the concentration of austistic children. This study aimed to determine the relative effectiveness between Al-qur'an murrotal and classical music in improving the concentration ability of children with autism.

Subjects and Method: This was a randomized control trial conducted at SLB Semesta Luar Biasa, Sooko, Mojokerto, East Java. A sample of 16 autistic children was selected for this study and randomized into two groups: (1) the experimental group who received Al-qurán murrotal, (2) the control group who received classical music. The dependent variable was concentration ability. The independent variable was type of music therapy. The data were collected by questionnaire and observation. Mean difference in concentration ability between the two groups was tested by t-test.

Results: At the baseline, the concentration ability in the Al-quran murrotal group (mean $=6.38 ; \mathrm{SD}=3.07$ ) was comparable with the classical music group (mean=6.00; $\mathrm{SD}=2.62)$, and it was statistically non-significant $(\mathrm{p}=0.794)$, indicating the randomization process had distributed all variables equally into the two groups. After the intervention, the concentration ability in the murrotal group (mean $=11.38 ; \mathrm{SD}=3.25$ ) was higher than in the classical music group (mean $=8.50 ; \mathrm{SD}=2.67)$, but it was not statistically significant $(\mathrm{p}=0.073)$.

Conclusion: The effectiveness of Al-qurán murrotal intervention and classical music therapy is comparable in improving concentration ability in children with autism.
\end{abstract}

Keywords: concentration ability, autistic children, Al-qur'an Murrotal, classical music

\section{Correspondence:}

Yufi Aris Lestari. School of Health Sciences Dian Husada, Mojokerto, East Java. Email: yufiarislestari@gmail.com. Mobile: 081234000677. 